\title{
Seek don't screen for oral cancer
}

\author{
Derek Richards \\ Editor, Evidence-based Dentistry
}

In this issue we look at a number of articles that address the topic of oral cancer screening. This is a subject that I have written about in the past. ${ }^{1}$ These three articles, an evidence-based clinical recommendation, ${ }^{2}$ a Cochrane review ${ }^{3}$ and a clinical trial ${ }^{4}$ in my view reinforce my perspective, or bias if you wish, that there is not sufficient evidence to support calls for screening programmes for oral cancer, although there is some weak evidence that it may be of some benefit in regions with a high incidence of the disease. It is however not in these areas where the largest push for screening programmes is seen.

Support for screening programmes in primary care is often promoted by those with interests in adjunctive technologies like toluidine blue, brush biopsy or fluorescence imaging. Yet neither the Cochrane review nor the ADA clinical recommendations found robust evidence to support them. Those with an interest in this area might like to take a look at a page of the website of the Scope Group (www.thescopegroup.com/ dental/case_history.htm), a UK dental marketing company that handles one of these adjunctive products.

That said, we are all aware that oral cancer is an important public and oral health issue and the dental team have an important role in its early detection and management. This role is very well laid out in a recently published BDA Occasional Paper. ${ }^{4}$ This paper is an excellent resource that provides a brief clear overview of oral cancer in the UK and clearly outlines what dentists and the dental team should do both to prevent oral cancer and detect early lesions.

The focus of the paper is to move practitioners away from screening towards case detection and to encourage them to improve the quality of their oral mucosal examination. It also highlights the first priority, that of primary prevention. As dental practitioners we see our patients regularly and have the opportunity to both initiate discussions about smoking, alcohol use and diet and provide advice about smoking cessation, reducing alcohol consumption and good diet. The BDA paper provides key messages and tips and links to a wide range of other helpful resources.

Another important role for the dental practitioner is to help raise awareness of oral cancer as a condition, for despite the fact that here in the UK there has been an annual mouth cancer awareness campaign for several years, it is evident from one of the other papers reviewed in this issue ${ }^{6}$ that there are still gaps in the public's understanding and awareness of oral cancer.

So for me the role of the dental team is clear, we must:

- be active in the primary prevention of the disease

- seek new cases by regular thorough oral mucosal examination of patients

- manage detected mucosal lesions appropriately

- support campaigns to raise awareness of oral cancer.

1. Richards D. Should we screen for oral cancer? Evid Based Dent 2009; 10: 98

2. Rethman MP, Carpenter W, Cohen EE, et al., American Dental Association Council on Scientific Affairs Expert Panel on Screening for Oral Squamous Cell Carcinomas. Evidence-based clinical recommendations regarding screening for oral squamous cell carcinomas. / Am Dent Assoc 2010; 141: 509-520.

3. Brocklehurst P, Kujan O, Glenny AM, Oliver R, Sloan $P$, Ogden G, Shepherd S. Screening programmes for the early detection and prevention of oral cancer. Cochrane Database of Syst Rev; issue 11.

4. Su WW, Yen AM, Chiu SY, Chen TH. A communitybased RCT for oral cancer screening with toluidine blue. J Dent Res 2010; 89: 933-937.

5. Speight P, Warnakulasuriya S, Ogden G (eds). Early detection and prevention of oral cancer: a management strategy for dental practice. BDA Occasional Paper No 6 (revised 2010). British Dental Association.

6. Grant E, Silver K, Bauld L, Day R, Warnakulasuriya $S$. The experiences of young oral cancer patients in Scotland: symptom recognition and delays in seeking professional help. Br Dent / 2010; 208: 465-471.

Evidence-Based Dentistry (2010) 11, 98. doi:10.1038/sj.ebd.6400748 